\title{
Legal Issue in the Matter of Cross-Border Insolvency in Indonesia Based on Law No. 37 Of 2004 on the Insolvency and Postponement of Debt Payment Obligation
}

\author{
Ilham Djaya ${ }^{1}$, Venty Indah Utami ${ }^{2}$ \\ Faculty of Law Universitas Kader Bangsa Palembang, Balai Harta Peninggalan Jakarta, \\ Indonesian Ministry of Law and Human Rights ${ }^{1,2}$ \\ \{ilhamdjaya06@gmail.com ${ }^{1}$,ventyindahutami@gmail.com² ${ }^{2}$.gm
}

\begin{abstract}
The issue of cross-border insolvency is growing rapidly in line of the global economic movement. The foreign elements on insolvency process raises question on the States' jurisdiction, the Court's authority to adjudicate the case of cross-border insolvency, the recognition of Indonesia's court decision on insolvency in another State, as well as the issue of Curator's authority to cooperate with another State officials. In Indonesian insolvency law, the issue of cross-border insolvency is limitedly regulated and unable to resolve the arising legal issues. The inconsistency of the application on territoriality and universality principle in Law No. 37 of 2004 on the Insolvency and Postponement of Debt Payment Obligation causes the difficulty on executing the insolvency assets in another State's territory and vice versa. Thus, an adequate cross-border insolvency legal framework is required to provide legal certainty for the business actors in Indonesia by adopting the existing legal framework through international agreements and reforming the Indonesian insolvency law.
\end{abstract}

Keyboard: cross-border insolvency; territoriality; universality

\section{Introduction}

\subsection{Background}

The globalization and free trade era drive the growth of business transaction, carried out both by individuals and corporations. The integration of international trade provides convenience for business transactions, therefore the commercial activities become borderless and may involve two or more foreign elements. The growth of business transactions brings the positive impacts to the commercial activity, e.g. the ease of investment on the equity-based investment in the form of foreign direct investment and portfolio investment in stock market. However, such ease of investment will lead to the possibility of another legal problem, for example regarding the cross- border insolvency issue.

Cross-border insolvency become an important issue that grows throughout the world, 
associated with the issue of legal certainty regarding State's jurisdiction on recognizing and executing the insolvency decisions. The cross-border insolvency occurs when a Debtor's inability to pay debt arises, and in such situation involves foreign elements, such as:

a. Debtor's estates located in foreign countries;

b. Such Debtor is not a subject of the State where the proceeding takes place;

c. Such Debtor has one or more foreign Creditor(s);

d. The commercial activities are conducted across the border of State.

The Indonesian insolvency law applies territoriality principle, which limits the effect of the Court's decision to merely be applied within the territory of that State where the proceeding has taken place. Under the Article 299 of Indonesian Insolvency Law jo. Article of 436 RV (Reglement of de Rechtsvordering, an Indonesian civil procedural regulation from the colonial era), the foreign Court's decision shall not be enforced without any prior reinvestigation by Indonesian Court. The territoriality principle contradicts with the universality principle implied by the Article 21 of Indonesian Insolvency Law, which states: "The insolvency comprises all of the Debtor's estates since the Court's decision is enforced as well as the Debtor's estates obtained whilst resolving the insolvency." This article implies that all of the Debtors estates within that State's territory or not, may be classified as the insolvency assets. In addition, this universality principle conflicts with the States sovereignty principle, in which a State has an absolute power on every matter within its territory.

In Indonesian domestic law, the foreign elements on insolvency process are merely regulated in 3 (three) articles: Article 212 to Article 214 of Indonesian Insolvency Law. This regulation is regarded as inadequate to resolve all the emanating legal issues on cross-border insolvency. Curators often face trouble on executing the Debtor's estates located in foreign countries -and thus, prejudice the right of the Creditor to receive the debt's payment. To resolve such problem, international law provides some solutions to facilitate the cross-border insolvency issues, for instance through UNCITRAL Model Law on Cross-border Insolvency with Guide to Enactment, which focuses on creating a framework for the commencement of proceedings, the recognition of foreign Court's decision, and cooperation between Member States in matters of cross-border insolvency. To the date, UNCITRAL Model Law have been adopted by 49 (forty-nine) States, and Indonesia is yet to adopt the Model Law, as well as the plan to reform the Indonesian insolvency law. Therefore, the legal certainty in the matter of crossborder insolvency in Indonesia leaves the business actors in Indonesia to be in wary.

Based on these facts, this paper will discuss the issueof Indonesian cross-border insolvency as well as the legal issue derived from the inadequacy of Indonesian cross-border insolvency regulations.

\subsection{Research Question}

This paper will discuss the issues on:

a. How is the cross-border insolvency being regulated in Indonesia?

b. What legal issues may derive from the inadequacy of Indonesian cross-border insolvency law?

c. What resolution may be carried out by Indonesia to resolve the legal issues in the matter of cross-border insolvency?

\section{Results and Discussion}


2.1 Overview Concerning Insolvency and Cross-border Insolvency in the Indonesian Law

Article 1 number 1 of the Indonesian Insolvency Law states that insolvency is a general confiscation of all assets of the Debtor whose settlement is carried out by the Curator under the supervision of the Supervisory Judge. In Indonesian insolvency law, insolvency occurs when a person experiences financial distress, has 2 (two) or more creditors and unable to pay off at least one overdue and collectable debt. When the insolvency was decided by the Court, the Debtor loses his right to manage all of his/her assets (automatic stay), and a Curator is required to carry out the settlement of insolvency assets to be distributed in pro rata, based on the claims of each Creditor.

Indonesian Insolvency Law limitedly regulates issues regarding the foreign elements in an insolvency process. Article 21 of the Insolvency Law clearly states that all assets of the Debtor are insolvency assets, regardless where are those assets located (the principle of universality, as stated in Articles 212-214 of the Insolvency Law). However, Curator often faces difficulties in executing insolvency assets outside Indonesia's territory, because Indonesian Court decisions could not be automatically applied in another States due to the sovereignty principle. The sovereignty principle can only be ruled out if there is a reciprocity among the States involved, for example through a bilateral agreement regarding insolvency among those States, for example, the Mutual Recognition and Mutual Enforcement of Singapore and Malaysia. Until now, Indonesia has implemented mutual legal assistance, but it is only limited to criminal matters and does not cover insolvency issues.

Article 436 Reglement op de Rechtvordering (RV) states that the decisions of foreign courts cannot be enforced in the jurisdiction of Indonesia, and the case must be filed, examined and decided by the Courts in Indonesia. Thus, if a person is declared insolvent by another State's Court, the person's estates in Indonesia's territory cannot be immediately executed and the relitigation must be carried out as a form of adjustment by a domestic law to foreign law used as the basis for an insolvency decision. This also applies to the opposite, in the case that the debtor's estates are located outside the territory of Indonesia, according to the Indonesian Insolvency Law, Creditors who wish to obtain the payment for their claim can only transfer all or part of their claim to a Third Party with intention that the Third Party takes full or part of the insolvency assets which is located outside the territory of Indonesia.

\subsection{Overview Concerning Insolvency and Cross-border Insolvency in International Law}

International law acknowledges the growing need for a specific legal framework pertaining foreign elements in insolvency proceedings. The integration of the world economy facilitates the involvement of foreign elements in a commercial activity, such as the different citizenship of the business actors or places of business that are outside the State's jurisdiction. The risk of cross- border insolvency is increased sharply as a result of the 1997 crisis monetary which affected the world, including in Asia. Prior to that time, there were no adequate regulations to resolve legal problems as a result of foreign elements in insolvency.

In general, a State can only allow the execution of a insolvency decision from another State if there is an agreement between those States, either through bilateral or multilateral agreements. Given the importance of regulating the cross-border insolvency and its relation to sovereignty principle, many countries have taken steps to establish cooperation in the field of insolvency with other countries through bilateral agreements, multilateral agreements, or by strengthening the diplomatic relations. In 2000, the European Union came with The European Union Convention on Insolvency Proceeding to carry out uniformity in insolvency regulations 
between its member States. In addition, Singapore and Malaysia also reached an agreement on insolvency through a bilateral agreement on Mutual Recognition and Mutual Enforcement of Republic of Singapore and Malaysia.

In relation to cross-border insolvency issue and as a solution to legal problems derived from insolvency cases which occurred after 1997 world monetary crisis, the United Nations (UN) through the United Nation Commission on International Trade Law (UNCITRAL) -an international trade law commission of United Nations, has compiled a model of legal frameworks called the UNCITRAL Model Law on Cross-Border Insolvency with Guide to Enactment. The Model Law is basically a non-legally binding law and thus serve no legal sanctions, but could serve as a reference and guidelines for States to deal with crossborder insolvency issues. Through such soft law, there are some rules in the matter of crossborder insolvency which may be adopted by the State, such as, among others:

a. Acceptance of foreign Curators as representatives in the domestic Court;

b. The recognition of foreign Court's insolvency decision; and

c. The cooperation and coordination either between Courts' officials or between curators, as well as the cooperation through the UNCITRAL Secretariat;

d. Ease of foreign courts insolvency decisions execution.

To date, 49 (forty-nine) States have adopted the Model Law into their cross-border insolvency domestic regulations, yet Indonesia has not been listed as one of its member States.

\subsection{Legal Issues in the Matter of Cross-border Insolvency in Indonesia}

The inadequacy of Indonesian Insolvency Law in the matter of cross-border insolvency conveys the legal issues especially on settling and resolving the insolvency. Those issues will be entertained as below.

\section{a) The Inconsistency of Indonesian Insolvency Law on Applying the Legal Principle}

As abovementioned, Indonesian insolvency law is based on territoriality principle, which limits the effect of the Court's decision to merely be applied within the territory of such State where the proceeding has taken place. It stipulated within the provision of Article 299 of Indonesian Insolvency Law jo. Article 436 RV, in which stated that the foreign Court's decision shall not be enforced without any prior reinvestigation and re-adjudication process by Indonesian Court. Meanwhile, under Article 21 jo. Article 212-214 Indonesian Insolvency Law, the insolvency shall include all of the Debtor's estates -which explicitly also put all of the Debtor's estates outside the Indonesian territory in custody.

The territoriality principle shall not be applied simultaneously with the universality principle, for to the reason of legal certainty. The legal principle shall be applied consistently for a law to be well-implemented and well-constructed. There are several States that previously applied the territoriality principle, nevertheless recently switched the principle to the latter (e.g. Japan and South Korea), meanwhile some States opt to hold onto the territoriality principle (e.g. Thailand and Singapore).

In the near future, it is necessary for Indonesia to choose one principle -either territoriality or universality principle, and thereafter apply it consistently through its insolvency laws. The international law stipulates that another State may apply the reciprocity principle in the matter of cross-border insolvency to Indonesia, if only Indonesia clearly applied the same principle. For instance, through the Japanese Law Relating to Recognition and Assistance for Foreign Insolvency Proceedings No. 129 of 2000, Japan intends to recognize another State Court's 
decision in the matter of cross-border insolvency as long as its Court decision were handled in the same manner by another State. In addition, the consistent application of a legal principle marks a well- constructed legal guidelines, for a law system of a State shall be built on the basis of the well- applied legal principle.

\section{b) The Challenge on Executing the Debtor's Estates Outside the Territory of Indonesia}

Under the Article of 98 jo. Article 101 of Indonesian Insolvency Law, Curator shall make certain all of the Debtor's estates -both foreign and domestic estates, to be kept in custody. Those estates shall then be registered by Curator, and once the Debtor were stated insolvent, all those registered estates subsequently be publicly auctioned through the authorized officials or to be privately marketed under the authorization of the Supervisory Judge. Yet, Curator often finds trouble whilst in attempt to keep the Debtor's foreign estates in custody, for the Indonesian Court decisions in the matter of cross-border insolvency has not yet been internationally recognized under the provisions of Article 299 of Indonesian Insolvency Law jo. Article 439 RV. The difficulty on executing the Debtor's estates emerges as the result of the sovereignty and territoriality principles applied by most States. The sovereignty principle states that each State is entitled to take control over their territory and therefore has an absolute authority within their borders. In the same time, Curator also face the principle of lex rei citae under Article 17 of $\mathrm{AB}$ (Algemene Bepalingen van wetgeving voor Indonesie, an Indonesian civil procedural regulation from the colonial era), which stipulates that if such foreign assets are the immovable properties, the law that applies is the law within the State where such asset is located.

To ease the execution process on the foreign estates, other States' recognition on both Indonesian Court's decision and the authority of Indonesian Curator, as well as the provisions regarding the cooperation between Curator and another State Court, are required. The existing provisions pertaining Indonesian Insolvency Law has not managed to regulate all the necessary requirements needed, hence the legal framework in the matter of cross-border insolvency in Indonesia shall be reformed in the near future. The present possible manner to be taken by the Curator regarding the execution of Debtor's foreign estates is through the relitigation process by providing the enforced Indonesian Court's insolvency decision before the foreign proceeding process as one of the legitimate evidences (affidavit). Yet, this re-litigation process may exhaust for the extensive amount of time, notably if such foreign proceeding holds a different legal system. Another risk that may arise due to the long re-litigation process is the reduction of selling value of the Debtor's estates, since such assets may become damaged during the long re-litigation process, thus put both Debtor and Creditor(s) at loss.

\section{c) The Creditors may Encounter the Legal Uncertainty on Their Right to Accept the Payment of Their Claim}

As a result of the inadequacy legal framework in the matter of cross-border insolvency in Indonesia, the Creditors often find themselves to be at loss. The execution of foreign Debtor's assets is difficult to be done, hence the duly executed estates which ought to be publicly auctioned or privately marketed under the authorization of the Supervisory Judge, could not be put in custody. Under the Article 212 of Indonesian Insolvency Law, when a Creditor perceives a trusted information regarding the Debtor's foreign assets, he/she may proceed to the Court to claim such estate as the payment of Debtor's debt. Meanwhile, due to Article 213 and Article 214 of Indonesian Insolvency Law, a Creditor that secures payments by transferring their right to 
a foreign Third Party, shall pay back the received amount to the Debtor's domestic assets accordingly.

Based on the aforementioned Indonesian Insolvency Law in the matter of cross-border insolvency, there is no such provision that provides the legal steps for Creditor to obtain his/her legal certainty in the matter of executing the foreign Debtor's assets. The existing international provisions on Indonesian Insolvency Law solely focused on the possibility of a Creditor to transfer their right to a foreign Third Party on a mutual basis, with prejudice to the settlement and resolution on the insolvency process. Accordingly, Creditors who wish to obtain the payment for their claim can only transfer all or part of their claim to a Third Party with intention that the Third Party takes full or part of the foreign insolvency assets.

The universality principle in Indonesian Insolvency Law only applies on such a passive manner, by prohibiting the business actors in Indonesia to abide to the international aspects of Court's insolvency decision. Consequently, it affects the execution process to obtain the foreign Debtor's estates. Then, as a result, if the Curator were unable to execute such foreign estates and the domestic Debtor's estates were insufficient to pay all the Debtor's debt, consequently the Creditors could not receive the full payment for their claim.

\subsection{Measures that can Be Taken to Resolve the Issue of Cross-Border Insolvency in Indonesia}

\section{a) Indonesia's Participation in International Agreements in the Matter of Cross-Border Insolvency}

The lack of provisions pertaining the cross-border insolvency in Indonesian Insolvency Law have resulted on some legal disparities, such as in terms of the recognition of Indonesian Court insolvency decision. As a result, many legal problems have arisen, notably on the difficulties to execute foreign Debtor's estates. As a result of the 1997 monetary crisis, many States all over the world experienced many issues related to foreign elements in insolvency. Yet, prior to 1997, there are no special legal frameworks provided to rule the cross-border insolvency issue. Therefore, to overcome such issue the UN through the United Nations Commission for International Trade Law (UNCITRAL) has compiled a Model Law on Cross Border Insolvency with Guide to Enactment, which may be used as a reference and solution to modernize and harmonize insolvency law. The Model Law aims to put respect on national legal procedures differences and does not attempt to carry out a substantive unification on national insolvency law, but rather, to provide a framework for inter-jurisdictional cooperation, offers simple solutions that may solve cross-border insolvency problems efficiently, and provides uniform rules for cross-border. The Model Law is a soft law, therefore it is not legally binding between its members and is only morally binding. However, the Model Law can be used as a reference for Indonesia to create a legal framework for cross-border insolvency regime.

In the Model Law, there are several legal frameworks provided that can be applied by the State related to cross-border insolvency, such as: recognition of foreign insolvency proceedings; introducing the term foreign main proceeding or foreign main trial process, namely a court forum that carries out the process of submitting an application for an insolvency decision to the execution of insolvency assets; cooperation between National Court with foreign Courts and Representatives; as well as mechanism for executing insolvency assets located outside the jurisdiction of a State.

To date, Indonesia has not actively participated in international agreements related to cross- 
border insolvency. In fact, legal problems arising out from cross-border insolvency could be minimized by Indonesia's active participation in international agreements, for instance:

a. adopting a legal framework that has been provided by the UNCITRAL Model Law, such as through the recognition of another State insolvency decision, cooperation between the Curator and another State's court, the mechanism of foreign insolvency assets execution, and Court's jurisdiction and competence related to cross-border insolvency;

b. undertake bilateral agreements related to cross-border insolvency as though Insolvency Agreement between Malaysia and Singapore which at least contains the recognition and enforcement of Court's insolvency decision in each state, the mutual recognition of Curator and Court authority, and the mechanism of insolvency assets execution in each state;

c. initiate cooperation arrangements related to cross-border insolvency matter in regional areas such as ASEAN. The establishment of the ASEAN Economic Community at the end of 2015, shows the real embodiment of ASEAN countries long-term vision to transform into a single integrated market. Therefore, it is righteously that there should be a harmonization of regulation related to cross-border insolvency in the ASEAN Economic Community in order to provide legal protection for each business actor in the ASEAN;

d. improve diplomatic relations with another state. Basically, international law promotes cooperation between States through good relations. Increased cooperation with another State through the maintenance of good diplomatic relations will facilitate the settlement of disputes that will arise in the future, including for issues related to cross-border insolvency.

\section{b) The need for Reformation of Indonesian Insolvency Law}

The Indonesian Insolvency Law, which has been present since 2004, aims to solve the problems of debts that exist in society, at the same time, protecting the rights of both Creditors and Debtors. However, in line with the development of society needs, the provisions in the Insolvency Law are deemed necessary to be reformed, especially in the matter of foreign elements in the insolvency proceeding. It is inevitable that the society needs will always develop from time to time, hence the law and regulations are required to be a dynamic instrument. The provisions regarding cross-border insolvency are now considered insufficient to provide legal certainty to the public, so the updated legal frameworks are required.

Based on these facts, reforming the Indonesian insolvency regime is necessary in order to provide legal certainty and meet the society needs. In addition to regulations on cross-border insolvency, there are several other provisions in the Indonesian insolvency law that are required to be renewed, for example: insolvency tests, insolvency requirements, automatic stay, the establishment of a supervisory agency for curator profession, and so on. If Indonesia became a Member State of international treaties or agreements, either the UNCITRAL Model Law or any other agreements, Indonesia can also adopt the legal framework provided in the national legislation related to insolvency. The reform of Indonesia's positive law related to cross-border insolvency must at least include:

a. Jurisdiction and authority of a forum to decide on an insolvency case with foreign elements; and

b. Recognition and execution of insolvency decision from another State, as well as an Indonesian insolvency decision in another State;

c. The extent of the Curator's authority to cooperate with the domestic Court where the foreign estate is located; 
d. Guarantee of similar treatment (reciprocal acknowledgments and enforcement of foreign judgments between the countries) if Debtor who is declared insolvent in a foreign country owns assets in Indonesia.

Beside to meet the development of society needs, the reformation of Indonesian insolvency law can influence the development of investment and business interests in Indonesia. Insolvency resolution is one of the global investment indicators provided by the World Bank or commonly referred to as Ease of Doing Business (EoDB), which is one of the objects of an economic assessment of a country. EoDB provides an objective assessment of regulations in the economic sector and the implementation of these regulations from 190 (one hundred and ninety) States all over the world. The higher the rank of a State, means the better administrative requirements of a business establishment, the provisions of economics laws as well as the implementation of legal provisions related to economy of a State. In addition to the insolvency resolution, there are 9 (nine) other indicators to determine the EoDB ranking of a State, such as ease of starting a business, dealing with construction permits, registering property, the ease of getting credit, taxes payment, and cross-border trading.

Based on data from the Doing Business page, in 2020 Indonesia is ranked 73 (seventy-three) out of 190 (one hundred and ninety) States. Compared to Indonesia's EoDB ranking in 2019, this ranking did not improve. In terms of resolving insolvency, Indonesia is ranked 38 (thirtyeight) over the past few years, which means that even though it is good enough, the improvement of insolvency law is still needed. A good EoDB ranking will be a positive consideration for foreign investors prior to invest in Indonesia, because it means that the regulations in the economic sector owned by such State are adequate and considered as a safe country to invest. Therefore, reforming Indonesian insolvency law regime, especially in terms of cross-border insolvency will greatly affect foreign investment which will boost the economy of Indonesia.

\section{Conclussions}

The development of technology and information in the globalization era provides convenience for economic and commercial transactions, which can now across a State boundaries (borderless). This certainly has a positive impact on the economy of a State, however on one hand it also brings legal problems regarding the presence of foreign elements in the event of insolvency, thus an adequate legal framework is needed. There are still disparities in the Indonesian insolvency law regime, where the provisions in it do not yet thoroughly regulate cross-border insolvency. There is still inconsistency in the application of the territoriality principle and the universality principle in the Indonesian Insolvency Law, which causes difficulty in executing foreign estates because there is no recognition of Indonesia's insolvency decisions abroad and vice versa. This results in legal uncertainty, especially for Creditors who have the right to collect their claim and receive payments from debtors.

To overcome this issue, Indonesia needs to participate actively in international agreements, both bilaterally and multilaterally. The legal framework provided in the international agreement can then be adopted into the national legislation regarding insolvency law in Indonesia. In addition, the Indonesian insolvency law regime needs to be reformed because the current Insolvency Law is deemed insufficient to meet the needs of the society, especially in the case of foreign elements in insolvency process. Improving the quality of insolvency resolution will have a great impact on improving Indonesia's economy since it will attract foreign investors to invest in Indonesia, for Indonesia is considered have a good legal 
framework in the economic sector and relatively safe to invest.

\section{References}

[1] Albayumi, Fuat, "Soft Law sebagai Sebuah Strategi: Studi Kasus Piagam ASEAN (ASEAN Charter)", Jurnal Ilmu Politik Hubungan Internasional Vol. 12 No. 2, Juli 2012

[2] Asnil, Dicky Moallavi, “UNCITRAL Model Law on Cross Border Insolvency sebagai Model Pengaturan Kepailitan Lintas Batas Indonesia dalam Integrasi Ekonomi ASEAN”; Undang: Jurnal Hukum Vol. 1 No. 2, 2018

[3] Atmadja, Dewa Gede, "Asas-Asas Hukum dalam Sistem Hukum”, Kertha Wicaksana. Volume 12, Nomor 2, 2018

[4] Badan Pembinaan Hukum Nasional (BPHN), Naskah Akademik RUU Kepailitan dan Penundaan Kewajiban Pembayaran Utang, 2018

[5] Gautama, Sudargo, Hukum Perdata Internasional Buku Kelima, Bandung, Alumni, 1998 Hardjaloka, Loura, "Kepailitan Lintas Batas Perspektif Hukum Internasional dan

[6] Perbandingannya dengan Instrumen Nasional di Beberapa Negara", Jurnal Yuridika Fakultas Hukum Universitas Airlangga Volume 30 No. 3, September 2015

[7] Imanullah, Moch Najib, Aspects Of International and Domestic Law Pertainining to The Establishment Of Asean Cross-Border Insolvency Regulations: An Indonesian Perspective, Indonesia Law Review, 2018

[8] LeMaster, Jane, "Recent Developments in Selected Asian Countries' Bankruptcy Laws: Should Multinational Company Strategists Be Concerned?" 2010, International Business \& Economics Research Journal Volume 6 Number 10

[9] Ratri, Pramesthi Dinar Kirana, "Urgensi Penerapan Aturan Kepailitan Lintas Batas berdasarkan UNCITRAL Model Law on Cross Border Insolvency di ASEAN", Belli ac. Pacis, Desember 2016

[10] Satrio, Adi, dkk., "Eksekusi Harta Debitor Pailit yang Terdapat di Luar Indonesia Dihubungkan dengan Pemenuhan Hak-Hak Kreditor", Ganesha Law Review Volume 2 Issue 1, May 2020

[11] Tomasic, Roman, Insolvency Law in East Asia, Ashgate Publishing, 2006

[12] Asean Economic Community, "Single Market and Production Base",http://investasean.asean.org/index.php/page/view/aseaneconomic- community/view/670/newsid/758/single-market-and-production-base.html

[13] Doing Business, "About Us", https://www.doingbusiness.org/en/about-us Doing Business, "Rankings", https://www.doingbusiness.org/en/rankings

[14] Porzycki, Dr Marek, Cross Border Insolvency, https://www.law.uj.edu.pl/ kpg/dydaktyka/international-insolvency-law/

[15] UNCITRAL Model Law on Cross-Border Insolvenc with Guide to Enactment, https://www.uncitral.org/pdf/english/texts/insolven/1997-Model-Law-Insol-2013Guide- Enactment-e.pdf

[16] UNCITRAL, Status: UNCITRAL Model Law on Cross-Border Insolvency (1997), https://uncitral.un.org/en/texts/insolvency/modellaw/cross-border_insolvency/status 